\title{
FACTORS ASSOCIATED WITH LOW CONCERN ABOUT FALLING IN PHYSICALLY ACTIVE OLDER PEOPLE
}

FATORES ASSOCIADOS À BAIXA PREOCUPAÇÃO EM CAIR DE IDOSOS PRATICANTES DE ATIVIDADE FISICA

FACTORES ASOCIADOS A LA BAJA PREOCUPACIÓN DE CAERSE DE PERSONAS DE LA TERCERA EDAD PRACTICANTES DEACTIVIDAD FÍSICA
Artur Rodrigues Fortunato ${ }^{1}$ (Physical Education Professional)

Eduardo Hauser ${ }^{2}$

(Physical Education Professional) Eduardo Capeletto'

(Physical Education Professional)

Daniel Rogério Petreça ${ }^{1,3}$

(Physical Education Professional)

Deise Jaqueline Alves Faleiro (Nutritionist)

Giovana Zarpellon Mazo (Physical Education Professional)

1. Universidade do Estado de Santa Catarina, Gerontology laboratory, Florianópolis, SC, Brazil.

2. Universidade Federal de Santa Catarina, Florianópolis, SC, Brazil. 3. Universidade do Contestado, Mafra, SC, Brazil.

\section{Correspondence:}

Center for Health Sciences and Sport (CEFID). Universidade do Estado de Santa Catarina (UDESC). Rua Pascoal Simone, 358, Coqueiros, Florianópolis, SC, Brazil. 88080-350.

giovana.mazo@udesc.br

\begin{abstract}
Introduction: Fear of falling is one of the main consequences of falls in the elderly; therefore, it is important to investigate the factors associated with the reduction of this fear. Objective: The objective of this study consisted of verifying the associated factors that best explain the low concern about falling in physically active older people. Methods: A total of 162 elderly people with a mean age of 69.95 $(S D=6.69)$ participated in the study. The diagnostic data sheet, the Falls Efficacy Scale-International, the Senior Fitness Test and anthropometric measurements were used to obtain data. Binary Logistic Regression was used in the data analysis to estimate the Odds Ratio (OR) and 95\% confidence intervals $(95 \% \mathrm{Cl})$. The $p<0.05$ Omnibus Test was used to assess the quality of the adjusted model, and the Hosmer-Lemeshow test was applied to verify the explanatory power of the model. Results: In the crude analysis, normal weight elderly subjects $(\mathrm{OR}=2.86,95 \% \mathrm{Cl}=1.32-6.20)$ with good levels of lower limb strength $(\mathrm{OR}=2.64,95 \% \mathrm{Cl}=1.38-5.06)$, are more likely to have low fear of falling. In the adjusted analysis, the model was able to explain $75 \%$ of endpoint occurrence. Conclusion: It is concluded that among the variables analyzed, age, BMI and lower limb strength best explain the low concern about falling in the elderly. Level of Evidence III; Study of nonconsecutive patients; without consistently applied reference "gold" standard.
\end{abstract}

Keywords: Elderly; Motor activity; Fear; Accidental falls.

\section{RESUMO}

Introdução: O medo de cair é uma das principais consequências de quedas em idosos, portanto, éimportante investigar os fatores associados à diminuição desse medo. Objetivo: O objetivo desse estudo consistia em verificar os fatores associados que melhor explicam a baixa preocupação com o medo de cair dos idosos praticantes de atividade física. Métodos: Participaram do estudo 162 idosos com média de idade de 69,95 $(D P=6,69)$. Para obtenção dos dados foi utilizada a ficha diagnóstica, o Falls Efficacy Scale-International, o Senior Fitness Test e as medidas antropométricas. Na análise de dados, utilizou-se a regressão logística binária para estimar a razão de chances (odds ratio, OR) e intervalos de confiança de $95 \%$ (IC 95\%). Para avaliar a qualidade do modelo ajustado foi utilizado o Teste Omnibus $p<0,05$ e o teste de Hosmer-Lemeshow para verificar o poder explicativo do modelo. Resultados: Na análise bruta, os idosos que possuem peso normal (OR=2,86; IC 95\%=1,32-6,20) e apresentam bons níveis de força dos membros inferiores (OR=2,64; IC 95\%=1,38-5,06) são aqueles que possuem mais chances de apresentar baixo medo de cair. Na análise ajustada, o modelo foi capaz de explicar 75\% da ocorrência do desfecho. Conclusão: Conclui-se que entre as variáveis analisadas, a faixa etária, o IMC e a força dos membros inferiores são as que melhor explicam a baixa preocupação com o medo de cair nos idosos. Nível de Evidência III; Estudo de pacientes não consecutivos; sem padrão de referência "ouro" aplicado uniformemente.

Descritores: Idoso; Atividade motora; Medo; Acidentes por quedas.

\section{RESUMEN}

Introducción: El miedo a caerse es una de las principales consecuencias de caídas en personas de la tercera edad, por lo que es importante investigar los factores asociados a la disminución de este miedo. Objetivo: El objetivo de este estudio consistía en verificar los factores asociados que mejor explican la baja preocupación con el miedo de caerse de personas de la tercera edad practicantes de actividad física. Métodos: En el estudio participaron 162 personas de la tercera edad con un promedio de edad de 69,95 (DP =6,69). Para la obtención de los datos se utilizó la fich a diagnóstica, el Falls Efficacy Scale-International, el Senior Fitness Test y las medidas antropométricas. En el análisis de los datos, se utilizó la regresión logística binaria para estimar la razón de chances (odds ratio, OR) e intervalos de confianza del 95\% (IC 95\%). Para evaluar la calidad del modelo ajustado se utilizó el Omnibus Test $p<0,05$ y el test de Hosmer-Lemeshow para verificar el poder explicativo del modelo. Resultados: En el análisis bruto las personas de la tercera edad que poseen peso normal $(O R=2,86, I C 95 \%=1,32-6,20)$ y presentan buenos niveles de fuerza de los miembros inferiores ( $O R=2,64$, IC $95 \%=1,38-5,06)$, son aquellos que 
tienen más probabilidades de presentar bajo miedo de caerse. En el análisis ajustado, el modelo fue capaz de explicar 75\% de la ocurrencia del desenlace. Conclusión: Se concluye que entre las variables analizadas, el grupo de edad, el IMC y la fuerza de miembros inferiores son las que mejor explican la baja preocupación con el miedo a caerse en las personas de la tercera edad. Nivel de evidencia III; estudio de pacientes no consecutivos; sin patrón de referencia "oro" aplicado uniformemente.

Descriptores: Anciano; Actividad motora; Miedo; Accidentes por caídas.

\section{INTRODUCTION}

The fear of falling is one of the main consequences of falls'. The possibility of falling is considered a constant concern and is a limiting factor in the performance of activities of daily living ${ }^{2}$. In addition to falls, changes in health and balance, cognitive and behavior factors, and visual deficiencies also increase the fear of falling and compromise the interaction with the environment inside and outside the home $\mathrm{e}^{3-4}$.

The fear of falling has different negative implications, including low health perception ${ }^{5-6}$, decreased quality of life, reduced mobility, functional decline, increased fragility, and depressive symptoms ${ }^{4}$. In addition, the difficulty in getting up from a chair, the need for assistive gait devices, the difficulty in using public transport, and self-reported balance problems are also associated with the fear of falling ${ }^{5}$.

With this context, older adults with greater fear of falling are more likely to have limitations in activities of daily living, a fact that can influence their quality of life ${ }^{7}$. Interestingly, a population-based study conducted in Ireland showed that $26.6 \%$ of the elderly population are afraid of falling ${ }^{8}$. Another study reported a rate of the fear of falling of $40.6 \%$ among healthy older adults ${ }^{9}$. It should be noted that the prevalence of the fear of falling is also higher among women ${ }^{7-10}$.

This high prevalence highlights the importance of knowledge about factors that can be modified to reduce the fear of falling ${ }^{8}$. Among these factors, individuals with lower performance in physical capacity tests have greater concern about falling ${ }^{11-12}$. In addition, older adults with fear of falling exhibit a lower walking speed and shorter step length, factors that can interfere with their daily life ${ }^{8}$. However, it remains unknown which physical capacities (strength, balance, flexibility, and aerobic endurance) explain the low fear of falling in physically active older adults. Thus, the objective of this study was to determine the factors that explain low fear of falling in older adults participating in physical activity.

\section{MATERIALS AND METHODS}

\section{Study design and participants}

This was a quantitative, exploratory, cross-sectional study. The population consisted of 187 older adults who participated in the university extension program (GETI) of the State University of Santa Catarina (UDESC). The GETI program offers educational and training projects as well as different physical activity modalities for the elderly population.

Using intentional, non-probability sampling, the following inclusion criteria were adopted: age $\geq 60$ years and participation in one of the physical activity projects of GETI. The sample was composed of 162 older adults.

\section{Instruments}

The following instruments were used:

Diagnostic chart: An interview was held to obtain data regarding participant identification (gender, age, and education level).

Falls Efficacy Scale-International (FES-I-BRAZIL): This scale is used to assess the fear of falling in older adults. It consists of 16 items related to activities of daily living and the concern about falling when performing these activities is scored from 1 (not at all concerned) to 4 (very concerned). The instrument shows excellent psychometric properties (Cronbach's $a=0.96$, ICC $=0.96)^{13}$ and transcultural adaptation to Brazilian older adults ${ }^{14}$.

Anthropometry: Body weight and height were measured according to the protocol of the International Society for the Advancement of Kinanthropometry $(I S A K)^{15}$. Body weight was measured with a Millenium ${ }^{\circledR}$ scale (model CA6000) to the nearest $0.1 \mathrm{~kg}$. Height was measured with a WCS ${ }^{\circledR}$ stadiometer (model Wood) to the nearest $0.1 \mathrm{~cm}$. These data were used to calculate the body mass index (BMI) as weight (kg) divided by the square of height ( $\mathrm{m})$.

Senior Fitness Test (SFT): This test battery was developed by Rikli and Jones ${ }^{16}$ to assess physical fitness in older adults. The SFT was validated and acceptable values of the criterion were obtained ( $r=0.71$ to 0.81 ). Reliability was evaluated using intraclass correlation procedures (R) and $R$ values ranged from 0.80 to $0.97^{16}$. The test battery consists of six measures of physical capacity: upper body strength (arm curl test), lower body strength (chair stand test), upper body flexibility (back scratch test), lower body strength (chair sit and reach test), agility/dynamic balance (8-ft up-and-go test), and aerobic endurance (6-minute walk test or stationary walking). The 6-minute walk test was chosen in the present study to assess aerobic endurance.

\section{Ethical aspects}

The present study was conducted in accordance with the ethical guidelines of Resolution No. 466/12 of the Brazilian National Health Council. The study was approved by the Ethics Committee on Research Involving Humans of UDESC (Protocol No. 185/07). All participants signed the free informed consent form and anonymity was guaranteed.

\section{Data collection procedure}

The data were collected by previously trained researchers. The instruments were applied in the form of a circuit in a sports gym, in the following order: 1) diagnostic chart; 2) FES-I-BRASIL; 3) anthropometry, and 4) SFT.

\section{Data analysis}

For analysis of the data, the participants were divided into age groups (60 to 69 years, 70 to 79 years, and $>80$ years). The cut-off points proposed by the American Academy of Family Physicians (AAFP) ${ }^{17}$ were used for the evaluation of BMl: $<22.0 \mathrm{~kg} \mathrm{~kg} / \mathrm{m}^{2}$ : low weight; 22.0 to 27.0 $\mathrm{kg} / \mathrm{m}^{2}$ : normal weight; $>27.0 \mathrm{~kg} / \mathrm{m}^{2}$ : overweight/obesity.

For evaluation of the FES-I-BRAZIL, the cut-off points suggested by Delbaere et al. ${ }^{18}$ were applied: score 16 to 22, low fear of falling; score 23 to 64 , high fear of falling.

In the SFT, the percentiles proposed by Rikli and Jones ${ }^{19}$ were used to classify the subjects. Values $<50^{\text {th }}$ percentile were classified as "poor" and values $\geq 50^{\text {th }}$ percentile were classified as "good" (the inverse analysis was performed for the agility and dynamic balance test).

Descriptive and inferential analysis was performed. The chi-squared test was applied to verify possible associations between variables and binary logistic regression was used to estimate odds ratios (OR) and 95\% 
confidence intervals $(94 \% \mathrm{Cl})$. Variables with $p \leq 0.20$ were entered into the model by backward selection using Wald's test. The quality of the adjusted model was evaluated using the Omnibus test $(p<0.05)$. The Hosmer-Lemeshow test was used to verify the explanatory power of the model. All analyses were performed using the IBM SPSS ${ }^{\bigotimes} 20.0$ software, adopting a level of significance of $5 \%$.

\section{RESULTS}

Eighty-two (50.6\%) of the 162 older adults participating in the study had high fear of falling, while 80 (49.4\%) had low fear. The mean age of the participants was $69.95(S D=6.69)$ years; the group with low fear of falling had a mean age of $69.11(S D=6.63)$ years and the group with high fear had a mean age of $70.78(\mathrm{SD}=6.68)$ years. There was no significant difference in age between groups ( $p=0.09$ ), with the present sample thus being homogenous in terms of this variable.

In crude analysis, older adults who had normal weight $(\mathrm{OR}=2.86$, $95 \% \mathrm{Cl}=1.32-6.20)$ and those who exhibited good levels of lower body strength $(\mathrm{OR}=2.64,95 \% \mathrm{Cl}=1.38-5.06)$ were significantly more likely to have low fear of falling. In addition, older adults aged 70 to 79 years had $49 \%$ lower odds of having low fear of falling. However, it should be noted that in the present study variables such as gender, education level, upper body strength, flexibility, and cardiorespiratory fitness were unable to explain the low fear of falling. (Table 1)

In adjusted analysis, the model was able to explain $75 \%$ of the occurrence of the outcome, as shown in Table 2. The variables that fit the model were: lower body strength, age group, gender, education level, $\mathrm{BMI}$, and falls in the last year. Thus, older adults with good lower body strength and normal weight were 2.89 times more likely to have no or low fear of falling.

\section{DISCUSSION}

Among the variables investigated in the present study, good performance in the lower body strength test best explained the low fear of falling. In addition, a normal BMI was associated with higher odds of low fear of falling. In agreement with our results, strength ${ }^{20}$ and $\mathrm{BM} \mathrm{I}^{5}$ have been shown to be associated with the fear of falling.

The present results showed that older adults with good muscle strength levels were three times more likely to have low fear of falling. According to Delbaere et al. ${ }^{21}$, reduced quadriceps muscle strength can explain the risk of falls perceived by older adults. Sarcopenia is known to increase with age due to a reduction in volume and death of some muscle fibers, which are replaced with fibrous or adipose connective tissue $^{22}$. Yamada et al. ${ }^{23}$, comparing older adults with and without sarcopenia, found a higher prevalence of the fear of falling in sarcopenic older adults. Furthermore, according to Trombetti et al..20, the decline in muscle mass, strength, power and physical performance contributes to increase the fear of falling.

In addition to muscle strength, in the present study, the age group of 70 to 79 years had $49 \%$ lower odds of having low fear of falling than older adults aged 60 to 69 years. However, participants older than 80 year were not less likely to have low fear of falling than older adults aged 60 to 69 years. Similarly, in a systematic review, Denkinger et al. ${ }^{10}$ reported the lack of consensus in the literature regarding the relationship between age and fear of falling. Among the 11 articles investigated in the review that evaluated the association between age and fear of falling, only five found such association, while six reported no significant association between age and fear of falling. Thus, high fear of falling probably has a multifactorial etiology, including sociodemographic factors, a history of falls and functional performance ${ }^{5}$, and even pain ${ }^{24}$. Thus, age is not the only variable that explains the fear of falling.
Table 1. Crude analysis of factors associated with low fear of falling in older adults participating in physical activity $(n=162)$.

\begin{tabular}{|c|c|c|c|}
\hline Variable & $\mathrm{n}$ & Crude analysis OR $(95 \% \mathrm{Cl})$ & $\mathrm{p}$-value \\
\hline \multicolumn{4}{|l|}{ Gender } \\
\hline Male & 32 & 1 & \\
\hline Female & 130 & $0.51(0.23-1.13)$ & 0.10 \\
\hline \multicolumn{4}{|l|}{ Age group } \\
\hline 60 to 69 years & 85 & 1 & \\
\hline 70 to 79 years & 65 & $0.51(0.26-0.99)$ & 0.04 \\
\hline$\geq 80$ years & 12 & $0.77(0.23-2.58)$ & 0.67 \\
\hline \multicolumn{4}{|l|}{ Education level } \\
\hline$\leq 8$ years & 79 & 1 & \\
\hline$>8$ years & 83 & $1.82(0.97-3.39)$ & 0.06 \\
\hline \multicolumn{4}{|c|}{ BMI } \\
\hline Overweight/obesity & 100 & 1 & \\
\hline Normal weight & 40 & $2.86(1.32-6.20)$ & $<0.01$ \\
\hline Low weight & 13 & $0.86(0.26-2.82)$ & 0.80 \\
\hline \multicolumn{4}{|c|}{ Falls in the last year } \\
\hline Yes & 33 & 1 & \\
\hline No & 86 & $1.92(0.84-4.38)$ & 0.12 \\
\hline \multicolumn{4}{|c|}{ Lower body strength } \\
\hline Poor & 77 & 1 & \\
\hline Good & 78 & $2.64(1.38-5.06)$ & $<0.01$ \\
\hline \multicolumn{4}{|c|}{ Upper body strength } \\
\hline Poor & 77 & 1 & \\
\hline Good & 79 & $1.05(0.56-1.97)$ & 0.87 \\
\hline \multicolumn{4}{|c|}{ Lower body flexibility } \\
\hline Poor & 81 & 1 & \\
\hline Good & 74 & $1.47(0.78-2.77)$ & 0.23 \\
\hline \multicolumn{4}{|c|}{ Agility and dynamic balance } \\
\hline Poor & 105 & 1 & \\
\hline Good & 49 & $0.90(0.45-1.77)$ & 0.76 \\
\hline \multicolumn{4}{|c|}{ Right upper body flexibility } \\
\hline Poor & 98 & 1 & \\
\hline Good & 55 & $1.09(0.56-2.11)$ & 0.79 \\
\hline \multicolumn{4}{|c|}{ Left upper body flexibility } \\
\hline Poor & 122 & 1 & \\
\hline Good & 32 & $0.68(0.31-1.50)$ & 0.34 \\
\hline \multicolumn{4}{|c|}{ Cardiorespiratory fitness } \\
\hline Poor & 93 & 1 & \\
\hline Good & 52 & $1.25(0.63-2.47)$ & 0.51 \\
\hline
\end{tabular}

Note: $\mathrm{n}=$ frequency; $\mathrm{OR}=$ odds ratio; $\mathrm{Cl}=$ confidence interval; $\mathrm{BMI}=$ body mass index.

Table 2. Adjusted analysis of factors associated with low fear of falling in older adults participating in physical activity $(n=162)$.

\begin{tabular}{|c|c|c|}
\hline Variable & OR $(95 \% \mathrm{Cl})$ & p-value \\
\hline \multicolumn{3}{|c|}{ Lower body strength } \\
\hline Poor & 1 & \\
\hline Good & $2.89(1.14-7.28)$ & 0.02 \\
\hline \multicolumn{3}{|c|}{ Age group } \\
\hline 60 to 69 years & 1 & \\
\hline 70 to 79 years & $3.35(0.51-21.86)$ & 0.20 \\
\hline$\geq 80$ years & $1.22(0.18-8.14)$ & 0.83 \\
\hline \multicolumn{3}{|c|}{ Gender } \\
\hline Male & 1 & \\
\hline Female & $0.59(0.20-1.74)$ & 0.34 \\
\hline \multicolumn{3}{|c|}{ Education level } \\
\hline$\leq 8$ years & 1 & \\
\hline$>8$ years & $0.78(0.32-1.88)$ & 0.58 \\
\hline \multicolumn{3}{|c|}{ BMI } \\
\hline Overweight/obesity & 1 & \\
\hline Normal weight & $2.89(1.04-8.05)$ & 0.04 \\
\hline Low weight & $1.03(0.18-5.82)$ & 0.96 \\
\hline \multicolumn{3}{|c|}{ Falls in the last year } \\
\hline Yes & 1 & \\
\hline No & $1.70(0.66-4.41)$ & 0.27 \\
\hline
\end{tabular}

Note: $\mathrm{OR}=$ odds ratio; $\mathrm{Cl}=$ confidence interval; $\mathrm{BMI}=$ body mass index. Omnibus test $=0.01$. 
Education level was also evaluated in the present study. Despite the lack of a statistically significant association, there was a trend in the crude analysis ( $p=0.06$ ) of participants with 8 years or more of schooling having low fear of falling. Studies conducted in Brazil to evaluate the association of different variables with the fear of falling found education level to be associated with the outcome in crude analysis ${ }^{25,26}$. However, as in the present study and in the adjusted models of these studies ${ }^{25,26}$, education level did not explain the fear of falling, but was part of the adjusted model. These findings suggest that education level is an important variable to diagnose fear of falling. However, when other variables are considered, education level does not seem to be as relevant to explain the fear of falling.

In addition to strength and age, the adjusted model showed that participants with normal weight were 2.89 times more likely to have low fear of falling than older adults with overweight/obesity. Our results corroborate the findings of Kumar et al. ${ }^{5}$ who observed increased odds of fear of falling in subjects with higher mean BMI. However, that study did not include low-weight subjects. In the present study, older adults with low weight were afraid of falling when compared to participants with overweight/obesity. One possible explanation is that severe leanness may also be associated with greater concern about falling in daily living.

The report of falls in the last year by the older adults of this study was not associated with low fear of falling. Although Hoang et al. ${ }^{27}$ indicated a relationship between a history of falls and fear of falling, such relationship was not found in the study of Kumar et al. ${ }^{5}$. Furthermore, a systematic review ${ }^{10}$ indicated the lack of consensus in the literature regarding this issue.
In view of the importance for older adults of the topic "fear of falling" in activities of daily living ${ }^{7}$, strategies to reduce the high fear of falling must be elaborated ${ }^{20}$. Muscle strength training, such as weight training, may be beneficial to reduce the fear of falling ${ }^{2}$. Strength training combined or not with balance exercises has also shown benefits ${ }^{29}$. Thus, strength exercises may be an important tool to reduce the fear of falls in older adults.

Limitations of this study include the lack of control for diseases and medications consumed by the older adults. In addition, although the sample consisted of physically active older adults participating in a university extension program, the level of physical activity was not measured directly, a variable that could be associated with the fear of falling.

\section{CONCLUSION}

The present results show that the variables that best explain the low fear of falling are muscle strength, BMl and age. Among these variables, it should be highlighted that strength and BMI are modifiable and can be developed in older adults in order to reduce the fear of falling, improving the quality of life of these individuals. In this respect, studies controlling for the level of physical activity, diseases and medications that influence the fear of falling should be conducted. In addition, longitudinal studies are necessary to determine the effects of strength training, and particularly interventions designed to reduce BMI, on the fear of falling.

All authors declare no potential conflict of interest related to this article

AUTHORS' CONTRIBUTIONS: Each author made significant individual contributions to this manuscript. ARF (0000-0001-6727-7723)*: conception of the study, writing of the article, data collection, analysis and interpretation of results; EH (0000-0002-7317-6010)*: conception of the study, writing of the article, data collection, analysis and interpretation of results; EC (0000-0003-4697-2166)*: writing of the introduction and method, data collection and final revision of the article; DRP (0000-0002-6006-4861)*: writing of the method and results, analysis and interpretation of results, final revision of the article; DJAF (0000-0001-9669-3734)*: writing of the discussion and conclusion, data collection, database organization; GZM (0000-0002-7813-5592)*: supervision of the study, writing of the analysis and interpretation of results and final revision of the article. ${ }^{*}$ ORCID (Open Researcher and Contributor ID).

\section{REFERENCES}

1. Fhon JRS, Rosset I, Freitas CP, Silva AO, Santos JLF, Rodrigues RAP. Prevalência de quedas de idosos em situação de fragilidade. Rev Saúde Pública. 2013;47(2):266-73.

2. Tinetti ME, Powell L. Fear of falling and low self-efficacy: A cause of dependence in elderly persons. J Gerontol. 1993;48 (Spec Issue):35-8

3. Brundle $C$, Waterman HA, Ballinger C, Olleveant $N$, Skelton DA, Stanford $P$, et al. The causes of falls: views of older people with visual impairment. Health Expect. 2015;18(6):2021-31.

4. Lopes KT, Costa DF, Santos, LF, Castro, DP, Bastone AC. Prevalência do medo de cair em uma população de idosos da comunidade e sua correlação com mobilidade, equilíbrio dinâmico, risco e histórico de quedas. Rev Bras fisioter. 2009;13(3):223-9.

5. Kumar A, Carpenter $\mathrm{H}$, Morris R, lliffe $\mathrm{S}$, Kendrick D. Which factors are associated with fear of falling in community-dwelling older people? Age ageing. 2014;43(1):76-84.

6. Malini FM, Lourenço RA, Lopes CS. Prevalence of fear of falling in older adults, and its associations with clinical, functional and psychosocial factors: The Frailty in Brazilian Older People Study. Geriatr gerontol internat. 2016;16(3):336-44.

7. Deshpande N, Metter EJ, Bandinelli S, Lauretani F, Windham BG, Ferrucci L. Psychological, physical and sensory correlates of fear of falling and consequent activity restriction in the elderly: The InCHIANTI Study. Am J Phys Med Rehabil. 2008;87(5):354-62.

8. Donoghue OA, Cronin H, Savva GM, O'Regan C, Kenny RA. Effects of fear of falling and activity restriction on normal and dual task walking in community dwelling older adults. Gait posture. 2013;38(1):120-4.

9. Uemura K, Shimada H, Makizako H, Doi T, Tsutsumimoto K, Yoshida D, et al. Effects of mild and global cognitive impairment on the prevalence of fear of falling in community-dwelling older adults. Maturitas. 2014;78(1):62-6.

10. Denkinger MD, Lukas A, Nikolaus T, Hauer K. Factors associated with fear of falling and associated activity restriction in community-dwelling older adults: a systematic review. Am J Geriatr Psychiatry. 2015;23(1):72-86.

11. Hauser E, Sandreschi PF, Parizzotto D, Araújo CDCR, Mazo GZ. Medo de cair e desempenho físico em idosos praticantes de atividade física. Rev educ fis. 2015;26(4):593-600.

12. Park J H, Cho H, Shin JH, Kim T, Park SB, Choi BY, et al. Relationship among fear of falling, physical performance, and physical characteristics of the rural elderly. Am J Phys Med Rehabil. 2014;93(5):379-86.

13. Yardley L, Beyer N, Hauer K, Kempen G, Piot-Ziegler C, Todd C. Development and initial validation of the Falls Efficacy Scale-International (FES-I). Age ageing. 2005;34(6):614-9.

14. Camargos FF, Dias RC, Dias J, Freire MT. Adaptação transcultural e avaliação das propriedades psicométricas da Falls Efficacy Scale-International em idosos brasileiros (FES-I-BRASIL). Rev Bras Fisioter. 2010;14(3):237-43.
15. Stewart A, Marfell-Jones M, International Society for the Advancement of Kinanthropometry. Internationa standards for anthropometric assessment. LowerHutt, New Zealand: ISAK; 2011. p. 48-80.

16. Rikli RE, Jones CJ. Development and validation of a functional fitness test for community-residing older adults. Journal of aging and physical activity. 1999;7(2):129-61.

17. American Academy of Family Physicians. American Dietetic Association; National Council on the aging Nutrition screening and intervention resources for healthcare professionals working with older adults. Nutrition Screening Initiative. Washington DC: American Dietetic Association, 2002.

18. Delbaere K, Close JC, Mikolaizak AS, Sachdev PS, Brodaty H, Lord SR. The falls efficacy scale internationa (FES-I). A comprehensive longitudinal validation study. Age ageing. 2010;39(2):210-6.

19. Rikli RE, Jones CJ. Aplicação do teste. In: Rikli RE, Jones CJ. Teste de aptidão física para idosos. Baruer: Manole; 2008. p. 66-98.

20. Trombetti A, Reid KF, Hars M, Herrmann, FR, Pasha E, Phillips EM, Fielding RA. Age-associated declines in muscle mass, strength, power, and physical performance: impact on fear of falling and quality of life. Osteoporos Int. 2016;27(2):463-71.

21. Delbaere K, Close JC, Brodaty H, Sachdev P, Lord SR. Determinants of disparities between perceived and physiological risk of falling among elderly people: cohort study. BMJ. 2010;341:c4165

22. Fleck SJ, Kraemer WJ. Fundamentos do treinamento de força muscular. 3 ed. Porto Alegre: Artmed; 2006. p. 237.

23. Yamada M, Nishiguchi S, Fukutani N, Tanigawa T, Yukutake T, Kayama H, et al. Prevalence of sarcopenia in community-dwelling Japanese older adults. J Am Med Dir Assoc. 2013;14(12):911-5.

24. Patel KV, Phelan EA, Leveille SG, Lamb SE, Missikpode C, Wallace RB et al. High prevalence of falls, fear of falling, and impaired balance in older adults with pain in the United States: findings from the 2011 National Health and Aging Trends Study. J Am Geriatr Soc. 2014;62(10):1844-52.

25. Antes DL, Schneider IJC, Benedetti TRB, D'Orsi E. Medo de queda recorrente e fatores associados em idosos de Florianópolis, Santa Catarina, Brasil. Cad Saúde Pública. 2013;29(4):758-68.

26. Moreira MA, Oliveira BS, de Moura KQ, Tapajós DM, Maciel ÁCC. A velocidade da marcha pode identifica idosos com medo de cair? Rev Bras Geriatr Gerontol. 2013;16(1):71-80.

27. Hoang OTT, Jullamate P, Piphatvanitcha N, Rosenberg E. Factors related to fear of falling among community-dwelling older adults. J clin nurs. 2017;26(1-2):68-76.

28. Dias RMR, Gurjão ALD, Marucci MDFN. Benefícios do treinamento com pesos para aptidão física de idosos. Acta fisiátrica. 2016;13(2):90-5.

29. Kumar A, Delbaere K, Zijlstra GAR, Carpenter H, lliffe S, Masud T, et al. Exercise for reducing fear of falling in older people living in the community: Cochrane systematic review and meta-analysis. Age ageing. 2016;45(3):345-52 